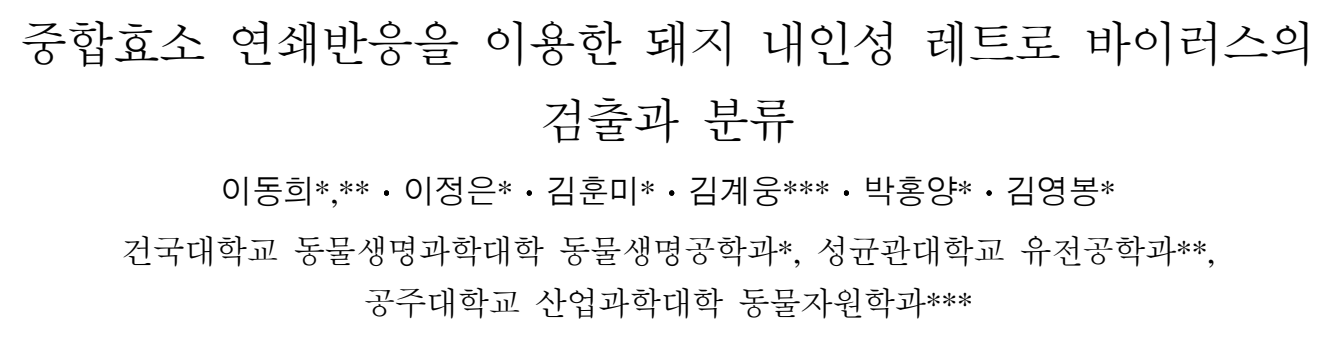

\title{
Detection and Classification of Porcine Endogenous Retroviruses by Polymerase Chain Reaction
}

\author{
D. H. Lee*,**, J. E. Lee*, H. M. Kim*, G. W. Kim***, H. Y. Park* and Y. B. Kim*
}

Department of Animal Biotechnology, College of Animal Bioscience \& Technology, Konkuk University*, Department of Genetic Engineering, Faculty of Life Science and Technology, Sungkyunkwan University**, Department of Animal Resources Science, College of Industrial Science, Kongju National University***

\section{ABSTRACT}

Pigs have been considered as an ideal source of donor organs because of their plentiful supply and their numerous anatomical and physiological similarities to the human in xenotransplantation. However, for the public health risks associated with the potential for porcine endogenous retrovirus (PERV) infection through xenograft from pig to human, the investigation of methods for elimination and/or control of PERV has been required. In this study we developed the detection and classification methods for PERV based on PCR using specific primers. PERV-A and PERV-B were found in all pigs including Berkshire, Duroc, Landrace, Yorkshire, miniature pig, and Korean native black pig from Jeju by PCR with type-specific primers for PERV. However, PERV-C was detected only from Duroc, miniature pig, and Korean native black pig from Jeju. PERV-A and PERV-B could be distinguished by PCR-RFLP with BamHI. These methods for PERV will be useful in rapid screening of safe organ for xenograft, furthermore, helpful in monitoring of PERV during and after xenotransplantation.

(Key words : Porcine endogenous retrovirus, Xenotransplantation, Detection, Classification, PCR, RFLP)

\section{I. 서 론}

동물로부터 바이오 장기를 생산하여 사람에 게 이식하려는 이종 간 장기 이식에 관한 연구 가 전 세계적으로 활발히 진행되고 있다 (Dorling 등, 2002; White와 Nicholson, 1999). 이 식하는 장기의 크기, 장기 제공 동물에 대한 번식 효율, 사육 기술, 경제 산업적 측면 등을
고려해 볼 때, 돼지가 장기 제공 동물로 가장 적절한 것으로 여겨지고 있다(Magre 등, 2002). 무균 돼지의 사육을 통하여 대부분의 외인성 병원균의 제거 및 차단이 가능하므로 이종 간 장기 이식에서 안전성을 높일 수 있으나, 돼지 자체가 가지고 있는 돼지 내인성 레트로 바이 러스(porcine endogenous retrovirus; PERV)의 존 재는 장기 이식 시 인수 공통 감염의 위험성을

Corresponding author: Young Bong Kim, Department of Animal Biotechnology, College of Animal Bioscience \& Technology, Konkuk University, Seoul 143-701, Korea.

Tel: 02-450-4208 / Fax: 02-455-1044 / E-mail: kimera@konkuk.ac.kr 
내포하고 있다. PERV는 내인성 바이러스이기 때문에 무균 사육을 통해서도 제거가 불가능하 므로, 장기 이식 시 면역 거부 반응과 더불어 해결해야 할 가장 큰 문제점 중의 하나이다 (Swindle, 1998; Swindle, 1996; Klymiuk 등, 2002; Magre 등, 2003; Klymiuk 등, 2003).

PERV는 1970년에 처음 보고되었으며, Retroviridae과 Gamma retrovirus 속에 속하는 대표적인 돼지의 내인성 바이러스로 알려져 있 다(Breese, 1970; Klymiuk 등, 2002). 염기 및 아 미노산 서열, 형태학적으로는 백혈병이나 면역 결핍증을 일으키는 murine leukemia virus $(\mathrm{MuLV})$ 와 feline leukemia virus (FeLV)와 같이 $\mathrm{\gamma}$ -레트로바이러스에 속하는 것으로 보고되었다 (Tacke 등, 2000). PERV는 3가지 종류(PERV-A, $-\mathrm{B},-\mathrm{C})$ 가 감염성 있는 바이러스를 생성 할 수 있는 것으로 알려져 있으며(Magre 등, 2003), envelope 유전자(env)의 염기서열에 따라서 분류 되었다. 이중 PERV-A와 PERV-B는 in vitro 상 에서 인간세포에 감염성을 나타내며, 다양한 숙주세포에 감수성을 나타내는 것으로 알려져 있다(Patience 등, 1997; Takeuchi 등 1998; Wilson 등, 1998; Weiss 등, 2000). 체내로의 전이 기작 은 SCID 마우스 및 면역 결핍된 마우스에서의 전이가 보고되었으나(van der Laan 등 2000; Deng 등, 2000), 이와 상반되게 전이가 되지 않 는다는 보고도 있으므로(Takeuchi 등, 1998; Paradis 등, 1999; Pitkin과 Mullon, 1999; Dinsmore 등, 2000; Levy 등, 2000; Specke 등, 2002a; Specke 등, 2002b) 아직까지 전이 기작 에 대한 논란이 일고 있는 실정이다.

인간세포를 포함한 많은 세포들은 PERV-A와 PERV-B에 대한 수용체를 가지고 있으며, 인간 세포에서의 PERV-A 수용체가 보고된 바 있다 (Ericsson 등, 2003). PERV-C는 돼지 세포에만 감염능을 보이는 ecotropic 바이러스로 알려져 있다(Mollnes 등, 1999; Patience 등, 1997). 그러 나 PERV-C가 PERV-A와 재조합 반응을 일으키 면서 그 감염성이 500 배나 증가하는 것으로 밝 혀져(Niebert와 Tonjes, 2005; Harrison 등, 2004) 아직까지 직접적인 인간세포로의 감염 증거는 없지만, 인수 공통 감염의 위험성을 완전히 배
제할 수는 없다.

본 연구진은 기존에 국내의 모든 돼지에서 $\mathrm{PERV}$ 가 존재함을 보고하였으며(김 등, 2004), 국내 돼지 및 미니 돼지의 gag, env 유전자에 대하여 보고(이 등, 2004; 이 등, 2005; Lee 등 2006)한 바 있다. 본 연구에서는 국내에서 사육 되고 있는 Berkshire, Duroc, Landrace, Yorkshire 종을 비롯하여 국내 미니 돼지 및 제주도 토종 흑돼지에서 PERV의 존재 유무 및 종류에 대하 여 확인 및 검출하는 중합효소 연쇄반응(Polymerase chain reaction; PCR) 기반 기법을 확립 하고자 하였다.

\section{ㅁ. 재료 및 방법}

\section{1. 공시 재료 및 genomic DNA 분리}

본 연구에 사용된 공시 재료는 다음과 같다. 경기도 $\mathrm{K}$ 종돈 농장에서 사육되고 있는 Yorkshire종 5두와 Landrace종 5두 그리고, 충남 C 종돈장에서 사육하고 있는 Duroc종 5 두 그리고 Berkshire종 5두를 이용하였으며, 국내 미니 돼 지는 경기도 평택 소재 PWG Genetics Korea 회 사로부터 제공 받은 두 종류의 무균 돼지 (M149, T1111)를, 제주 토종 흑돼지는 제주 농 가에서 10 두를 선정하여 이용하였다.

국내 재래 돼지는 모발을 채취하여 $4^{\circ} \mathrm{C}$ 저온 상태로 유지하여 실험실로 운송 한 후, QIAamp Mini Kit(QIAGEN, USA)를 이용하여 genomic DNA를 추출하고 종별로 pooling하여 실험에 이용하였다. 미니 돼지와 제주 토종 흑돼지는 혈액을 채취하여 Ficoll gradient 방법 (이 등, 2004)에 의하여 Peripheral Blood Mononuclear Cells (PBMCs)를 분리하고, 이를 국내 돼지에서 사용한 방법과 동일하게 genomic DNA를 추출 하여 실험에 사용하였다.

\section{PERV proviral DNA 증폭 - pol}

각각의 공시 시료 내에 PERV 존재 여부를 확인하기 위하여 PERV의 유전자 염기서열 중 가장 높은 상동성을 보이는 pol 유전자를 이용 
하여 primer를 제작하여 시험하였다(Fig. 1). 증 폭의 특이성 및 효율성을 높이기 위하여 nested PCR을 수행하였으며, 사용된 primer들의 염기 서열은 Table 1 과 같다. 먼저 N-pol1과 N-pol2 를 이용하여 1 차 PCR을 수행한 후, N-pol3와 $\mathrm{N}-\mathrm{pol} 4$ 를 이용하여 2차 PCR을 수행하였다. 각 PCR 반응에는 $50 \mathrm{ng}$ genomic DNA를 주형으로 사용하였으며, 1 차 PCR 반응에 사용된 반응물 은 반응 완충액 내 $1.5 \mathrm{mM} \mathrm{MgCl}_{2}, 1 \mathrm{mM}$ dNTPs, primer는 각각 10 pmole, 2 unit Taq (Super-Bio, Korea)을 사용하였다. PCR 조건은 GeneAmp PCR system 9700 (Perkin-Elmer, USA) 을 이용하여 $94^{\circ} \mathrm{C}$ 3분으로 1 회 반응을 수행한 후, $94^{\circ} \mathrm{C}$ 에서 10 초 간 변성반응, $45^{\circ} \mathrm{C}$ 에서 10 초 간 결합반응, 그리고 $72^{\circ} \mathrm{C}$ 에서 10 초 간 신장반 응을 30회 반복하여 실시하고, $72^{\circ} \mathrm{C}$ 에서 30 초 간 반응시킨 후 반응을 종결하였다. 증폭된 산 물은 3차 멸균수를 이용하여 1,000배 희석한 후, $2 \mathrm{ul}$ 를 취하여 2차 PCR 시 주형으로 이용하 였다. 2차 PCR 반응물의 조성은 1 차 반응에서 와 동일하게 사용하였다. 2차 반응의 PCR 조건 은 $94^{\circ} \mathrm{C}$ 에서 10 초 간 변성반응, $68^{\circ} \mathrm{C}$ 에서 10 초 간 결합반응, 그리고 $72^{\circ} \mathrm{C}$ 에서 10 초 간 신장반 응을 30회 반복하여 실시하고, $72^{\circ} \mathrm{C}$ 에서 30 초 간 반응시킨 후 반응을 종결하였다. 증폭된 산 물은 $3 \%$ 아가로즈 겔에서 전기영동을 수행하 여 확인하였다.

\section{PERV proviral DNA 증폭-PERV의 분류}

PERV-A, PERV-B, PERV-C의 종류 별로 분 류하는 PCR을 위한 primer는 GenBank에 등록 된 모든 $\mathrm{PERV}$ 의 env 유전자 염기서열을 참고 하여 각 종류별로 가장 잘 보존된 부분을 선택 하여 제작하였다 (김 등, 2006; Mang 등, 2001). 제작된 primer의 염기서열은 Table 1 과 같다. $\mathrm{PCR}$ 에 사용된 반응물의 조성은 $\mathrm{pol}$ 유전자 단 편의 증폭의 경우와 동일하게 사용하였으며, $\mathrm{PCR}$ 조건은 $94^{\circ} \mathrm{C}$ 3분으로 1회 반응을 수행한 후, $94^{\circ} \mathrm{C}$ 에서 10 초 간 변성반응, PERV-A와 $\mathrm{PERV}-\mathrm{B}$ 의 경우는 $55^{\circ} \mathrm{C}$ 에서, PERV-C의 경우는 $58^{\circ} \mathrm{C}$ 에서 10 초 간 결합반응, 그리고 $72^{\circ} \mathrm{C}$ 에서 10 초 간 신장반응을 30 회 반복하여 실시하고, $72^{\circ} \mathrm{C}$ 에서 30 초 간 반응시킨 후 반응을 종결하 였다. 증폭된 산물은 $3 \%$ 아가로즈 겔에서 전기 영동을 수행하여 확인하였다.

\section{PERV-A와 PERV-B의 Restriction frag- ment length polymorphism (RFLP)}

PERV-A와 PERV-B를 구별하는 PCR-RFLP를 수행하기 위한 primer의 염기서열은 Table 1 과 같다. PCR에 사용된 반응물 조성은 pol 유전자 단편의 증폭의 경우와 동일하게 사용하였으며, $\mathrm{PCR}$ 조건은 $94^{\circ} \mathrm{C}$ 3분으로 1 회 반응을 수행한 후, $94^{\circ} \mathrm{C}$ 에서 10 초 간 변성반응, $55^{\circ} \mathrm{C}$ 에서 10 초

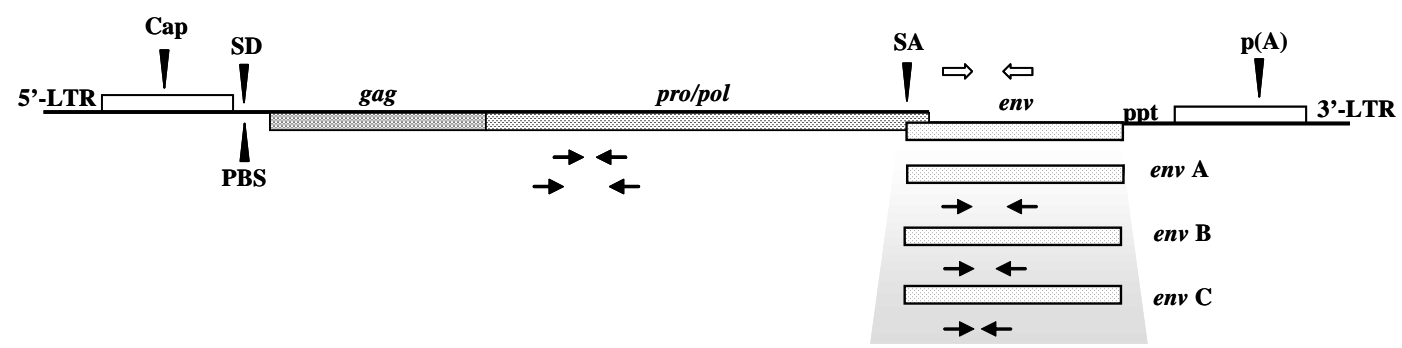

Fig. 1. Schematic representation of PERV. The abbreviations are: SD, splicing donor; PBS, primer binding site; SA, splicing acceptor; ppt, polypurine tract. Arrows indicate primer sets used in this study: closed arrows in pro/pol region for PERV detection (N-pol1, $\mathrm{N}$-pol3, N-pol4, N-pol2 in order); closed arrows in env region for type-specific detection for PERV-A (A6F \& A6R), PERV-B (B2.5F \& B2R), and PERV-C (Cenv3 \& Cenv4), respectively; open arrows in env region for PCR-RFLP (PERV-F \& PERV-R). 
Table 1. Primer sets used in this study.

\begin{tabular}{|c|c|c|c|c|}
\hline Primer name & \multicolumn{2}{|c|}{ Primer sequence (5' to 3') } & PCR Product size & Usage \\
\hline \multirow{2}{*}{ N-pol1 } & $* * * * * * * * * * * * * * * * * * * *$ & & \multirow{3}{*}{469 bp } & \multirow{6}{*}{ PERV pol specific } \\
\hline & GATGAGCGTAAGGGAGTAGC & & & \\
\hline \multirow[t]{2}{*}{ N-pol2 } & $* * * * * * * * * * * * * * * * * * * *$ & & & \\
\hline & $* * * * * * * * * * * * * * * * * * * *$ & & \multirow{3}{*}{217 bp } & \\
\hline N-pol3 & CCATACTGGTCAAGGACGCT & & & \\
\hline N-pol4 & $\begin{array}{l}* * * * * * * * * * * * * * * * * * * * \\
\text { TCATCAGTCTCTTCAGGCAG }\end{array}$ & & & \\
\hline $\mathrm{A} 6 \mathrm{~F}$ & $\begin{array}{l}\mathrm{c} * * * * * * * \mathrm{a} * \mathrm{e} \text { a } \mathrm{a} * * \mathrm{a} * \mathrm{a} \text { a } * \text { a c } \\
\text { TCTGGGAGAAAGAAAGGATCTG }\end{array}$ & & \multirow{2}{*}{485 bp } & \multirow{2}{*}{ PERV-A specific } \\
\hline A6R & $\begin{array}{l}\text { a а } а * * * * * * * a * * a * * * * * \text { a } * \text { a } \\
\text { CGATTAAAGGCTTCAGTGTGGT }\end{array}$ & & & \\
\hline $\mathrm{B} 2.5 \mathrm{~F}$ & $\begin{array}{l}\mathrm{a} * * \mathrm{~b} * * * * * * * \mathrm{a} * * \mathrm{a} \mathrm{b} * * \mathrm{ad} * * \\
\text { GGGCAAGTACAAAGTGATGAAA }\end{array}$ & & \multirow{3}{*}{377 bp } & \multirow{3}{*}{ PERV-B specific } \\
\hline \multirow{2}{*}{ B2 R } & а а $* * * * * * \mathrm{c} * * *$ a а а $* * * * * * *$ & & & \\
\hline & TTCTAGGCGTGTTGGTAGGAAT & & & \\
\hline Cenv3 & $\begin{array}{l}* * * * * * * \mathrm{a} * * * * * * * * * * \\
\text { TGGATTAGAACTGGAAGC }\end{array}$ & & \multirow{2}{*}{238 bp } & \multirow{2}{*}{ PERV-C specific } \\
\hline Cenv4 & $\begin{array}{l}* * * * * * * * * * * * * * * * * * \\
\text { TTTGACCCGTCAAGACCG } \\
* \text { a } * * * \text { a } * * * \text { a а а а a } * * * * \text { a b }\end{array}$ & P E R V - A & & \\
\hline PERV-F & $\begin{array}{l}* * * * * * * * * \mathrm{e} * \mathrm{a} * * * * * \mathrm{a} * * * \\
\text { CAAAAGTGGGTAAATGGTATG } \\
* * * * \mathrm{a} * * * * * * * * * * * * * * *\end{array}$ & P E R V -B & $\begin{array}{ll}\text { PERV } & \text { A: } 509 \mathrm{bp} \\
\text { PERV } & \text { B: } 557 \mathrm{bp}\end{array}$ & \multirow[t]{2}{*}{ RFLP } \\
\hline PERV-R & $\begin{array}{l}* \mathrm{a} * \mathrm{a} a * * * * * * \text { a } a * \mathrm{a} * * \mathrm{a} * * \\
\text { CAAAGGTGTTGGTGGGATGG }\end{array}$ & P E R V -B & & \\
\hline
\end{tabular}

Abbreviations are: PCR, polymerase chain reaction; PERV, porcine endogenous retrovirus; pol, polymerase gene; RFLP, restriction fragment length polymorphism. The primers were determined by analysis of reported sequence of PERV on GenBank. The sequence identity between the primers and the sequences on GenBank are as follows; *, 100\% matched; a, above $95 \%$ matched; b, above $90 \%$ matched; c, above $85 \%$ matched; d, above $80 \%$ matched; e, below $80 \%$ matched.

간 결합반응, 그리고 $72^{\circ} \mathrm{C}$ 에서 10 초 간 신장반 응을 30 회 반복하여 실시하고, $72^{\circ} \mathrm{C}$ 에서 30 초 간 반응시킨 후 반응을 종결하였다. 증폭된 산 물은 $3 \%$ 아가로즈 겔에서 전기영동을 수행하 여 확인하였다. 증폭된 산물은 PCR clean-up kit (QIAGEN, USA)를 사용하여 정제 한 후, 5 unit 의 BamHI (Takara, Japan)을 $37^{\circ} \mathrm{C}$ 에서 6시간 처 리 한 후, $3 \%$ 아가로즈 겔 상에서 전기영동을 수행하여 확인하였다.

\section{III. 결과 및 고찰}

\section{1. 돼지 genomic DNA에서의 PERV 검출- Nested PCR of pol region}

돼지의 genomic DNA로부터 provirus 상태로
존재하는 PERV를 검출하기 위하여, PERV의 유전자 염기 서열 중 가장 보존이 잘 되어 있 는 pol 유전자 부위를 선정하여 이에 특이적인 primer를 제작하였으며, 또한 특이성을 높여서 위양성(false positive)을 배제하기 위하여 nested $\mathrm{PCR}$ 을 수행하였다. 선정된 primer의 가용성을 측정하기 위하여 PERV가 발현되는 세포주로 알려진 돼지 신장 유래 PK15 세포주(Patience 등, 1997)를 이용하여 실험을 수행하여 본 결 과, 본 연구에서 사용한 primer로 PK15에서 $\mathrm{PERV}$ 를 검출할 수 있음을 확인하였다(Fig. 2). 검출의 감수성(sensitivity)을 확인하기 위하여 PK15 세포 각각 $1,3,5,10$ 개를 직접 주형으로 하여 PCR을 수행한 결과, 세포 1 개부터 PERV 의 존재를 검출 할 수 있음을 확인 하였다(data not shown). 


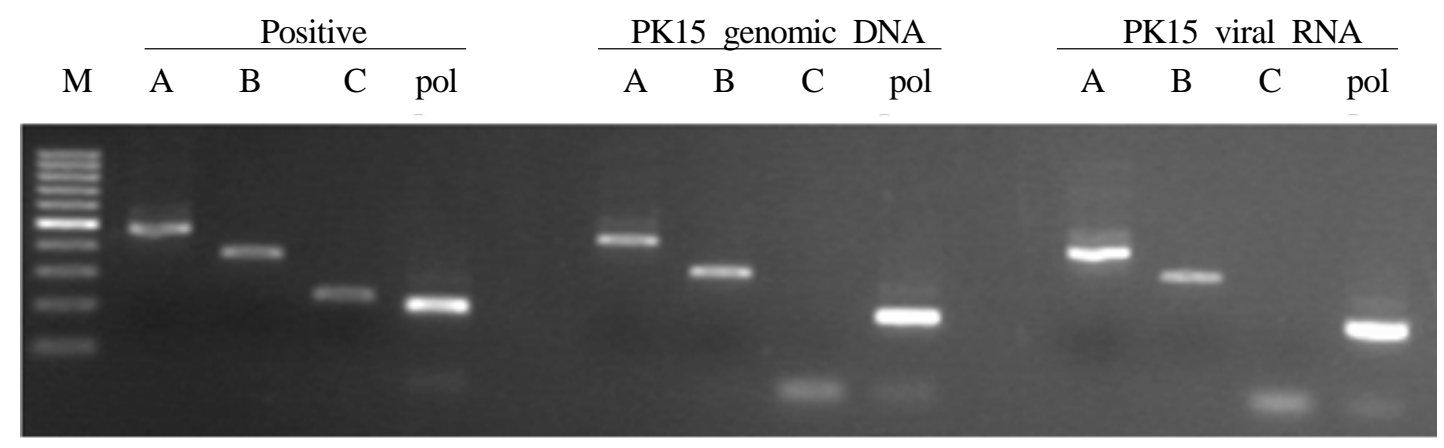

Fig. 2. Electrophoresis patterns of amplified products using type-specific primer sets (A6F \& A6R for PERV-A, B2.5F \& B2R for PERV-B, and Cenv3 \& Cenv4 for PERV-C) and pol primer set (N-pol3 \& N-pol4) in PK15 cell line. Plasmids containing env of PERV$\mathrm{A},-\mathrm{B}$ and $-\mathrm{C}$, respectively, and containing whole gag-pol region were used as template in positive control. PK15 known as a cell line producing PERV genomic DNA and viral RNA were tested.

PERV pol 유전자 특이적인 primer를 이용한 $\mathrm{PCR}$ 을 통하여 본 연구에서 사용된 공시 돼지 모두에서 PERV가 검출됨을 확인 할 수 있었다 (Fig. 3). 이는 사용된 primer와 방법은 다르지 만, 기존에 본 연구실에서 보고한 국내 돼지에 존재하는 PERV의 분포에서 모든 돼지에서 $\mathrm{PERV}$ 를 발견할 수 있었던 것과 동일한 결과로 서, 돼지 내에 PERV가 광범위하게 존재함을 알 수 있다(김 등, 2004). 또한 새로이 도입된 primer는 reverse transcriptase (RT)-PCR을 통하 여 돼지 PK15 세포 배양액 또는 혈액 속에 존 재하는 RNA 상태의 바이러스 또한 검출할 수 있었다(Fig. 2).

\section{2. $\mathrm{PCR}$ 을 이용한 $\mathrm{PERV}$ 의 분류}

이종 간 장기 이식 시 인수 공통 감염원으로 부각되고 있는 PERV는 다양한 세포로의 감염 성이 조사되었다. 이 바이러스는 돼지에서 생 산되지만, 돼지 이외에도 인간을 포함한 여러 원숭이 종류, 햄스터, 개, 쥐, 고양이, 박쥐, 햄 스터를 비롯한 여러 포유동물과 심지어 곤충 세포에까지 감염성을 보여준다(Patience 등, 1997; Takeuchi 등 1998; Wilson 등, 1998; Weiss 등, 2000). 인간 신장 세포에서 유래된 293세포 의 경우 PERV-A는 PERV-B에 비해 약 3 배 가
량 높은 감염능을 보이며, 자궁경부암 세포인 $\mathrm{HeLa}$ 세포의 경우에는 57배나 높은 감염능을 보인다(Takeuchi 등, 1998).

본 연구에서는 PERV-A, PERV-B 및 PERV-C 각각에 특이적인 primer를 작성하여, 각 종류를 구분할 수 있는 최적의 PCR 조건을 수립하였 다. pol 유전자 단편의 증폭에서와 마찬가지로, PK15 세포에서 추출한 genomic DNA와 PK15 세포 배양액에서 분리한 바이러스의 RNA를 이 용하여 각각의 PCR을 통한 PERV 분류의 가용 성을 측정하였다.

각 종류의 PERV에 특이적인 primer를 이용 하여 PCR을 수행한 결과, PK15 세포에서는 PERV-A와 PERV-B만 검출되고, PERV-C는 검 출할 수 없었다(Fig. 2). 본 결과는 기존 Clemenceau 등(2002)에 의하여 보고된 바와 동일한 것 으로 사료된다. PK15를 배양한 세포 배양액에 서 추출한 바이러스를 이용한 RT-PCR도 동일 한 결과를 확인 할 수 있었다. 따라서 PK15 세 포주에는 PERV-A 및 PERV-B가 존재하며, PERV-C의 경우는 PCR 방법으로 검출하기에는 적은 양이 존재 하거나 PERV-C가 존재하지 않 음을 의미한다.

국내 돼지에서의 PERV 분류 결과는 Fig. 3에 서 보는 바와 같이 무균돼지에서는 세 가지 종 류의 PERV가 모두 검출됨을 확인 할 수 있었 


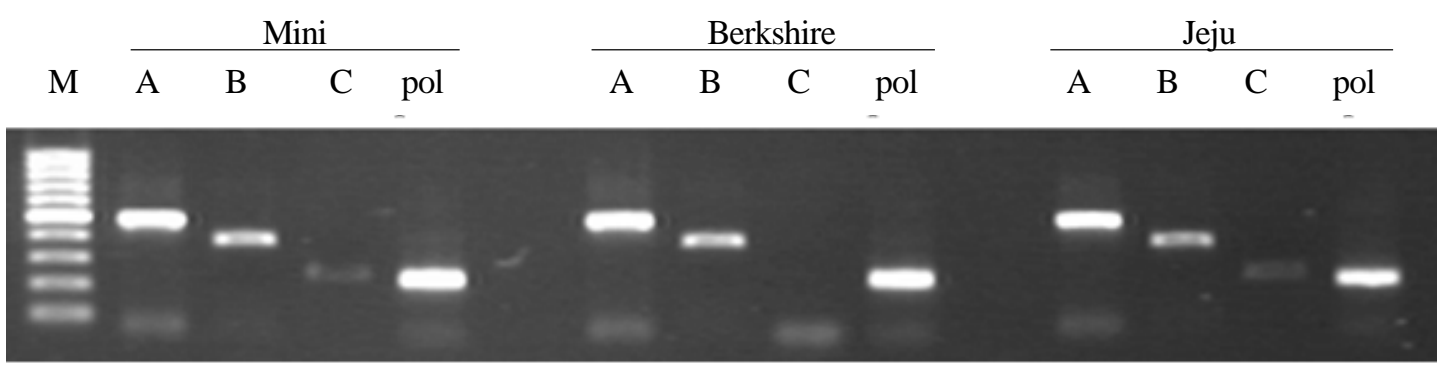

Fig. 3. Detection of PERV by PCR with type-specific primer sets (A6F \& A6R for PERV-A, B2.5F \& B2R for PERV-B, and Cenv3 \& Cenv4 for PERV-C) and pol primer set ( $N$ pol3 \& N-pol4) from genomic DNA of miniature pig, Berkshire breed, and Korean native black pig from JeJu.

다. PERV에 대한 보다 정확한 정량 분석을 위 해서는 real time PCR 등의 측정 방법이 필요하 나, 본 연구에서 정성적인 분석을 통하여서는 PERV-A가 가장 강하게 검출되었으며, 그 다음 으로 PERV-B였으며, 상대적으로 PERV-C는 매 우 약하게 검출됨을 확인 할 수 있었다. 이는 본 연구진이 PERV env 유전자의 클로닝 실험 을 통하여 분포도를 조사해 본 결과, PERV-A : PERV-B : PERV-C의 비율이 53:46:1로 나온 결 과와 부합하는 것으로 사료된다(Lee 등, 2006).

\section{3. 돼지에서 PERV-C의 구분}

본 연구에서 Berkshire, Duroc, Landrace, Yorkshire, 국내 미니돼지 및 제주 토종 흑돼지 의 genomic DNA를 시료로 하여, PERV-C에 특 이적인 primer를 이용하여 PERV-C의 존재 여 부를 확인한 결과, 음성대조구인 PK15 세포에 서의 결과와 비교했을 때, Berkshire, Landrace, Yorkshire에서는 PCR 산물이 나타나지 않았으 나, Duroc종에서 매우 낮은 양의 PCR 산물이, 국내 미니돼지와 제주 토종 흑돼지에서는 상대 적으로 높은 양의 PCR 산물이 확인되었다(Fig. 4). 이와 같은 차이가 품종 간의 차이인지, 아 니면 개체 간의 차이인지에 대해서는 본 연구 를 통해서는 확인할 수 없었으며, 이를 위해서 는 각 품종에 대하여 보다 많은 개체에 대한 실험과 분석이 필요하리라 사료된다.

PERV-C의 정량적 분석을 위해서는 real time $\mathrm{PCR}$ 등의 방법이 도입되어야 할 것으로 사료

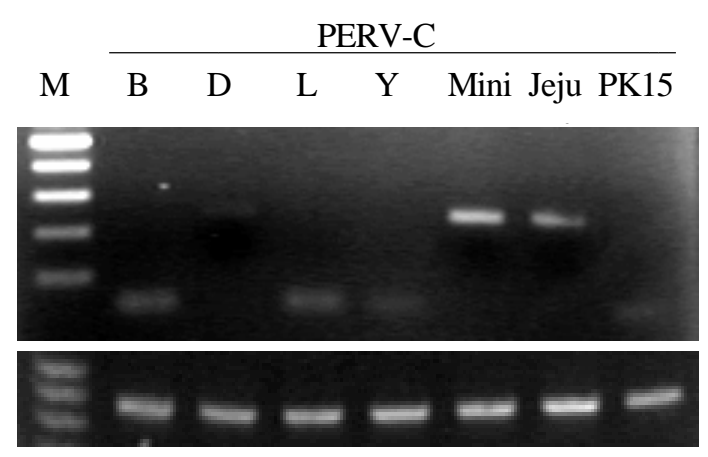

GAPDH

Fig. 4. Detection of PERV-C by PCR with PERV-C specific primer set (Cenv3 \& Cenv4) in pigs. The abbreviations are: B, Berkshire; D, Duroc; L, Landrace; Y, Yorkshire; Mini, miniature pig; Jeju, Korean native black pig from Jeju. PK15 was used as a negative control. Glyceraldehyde-3-phosphate dehydrogenase GAPDH) was used as a internal PCR control.

되나, 본 연구에서 사용된 PERV-C 특이적인 primer를 사용하여 정성적으로 PERV-C의 존재 여부를 확인하는 데는 어려움이 없을 것으로 사료된다.

PERV-C는 인간세포에 감염되지 않는 바이러 스로 알려져 있다(Takeuchi 등, 1998). 하지만 최근 PERV-A와 PERV-C간의 재조합에 의해 생 성된 바이러스는 PERV-A에 비해 500배나 높은 인간세포로의 감염능을 보임으로서, PERV 재 
조합체에 의한 이종 간 장기 이식에서의 위험 성을 상기시킨 보고가 있다(Harrison 등, 2004). 이 재조합 바이러스는 PERV-C를 기본 주형으 로 가지며 env 유전자 중 receptor binding domain 부위만을 PERV-A로 가진다. 특히 PERV-A와 PERV-B에 비해서 PERV-A와 PERV$\mathrm{C}$ 는 $85 \%$ 이상의 상당히 높은 염기서열 상동성 을 가지고 있으므로, 재조합에 의해서 인간세 포로의 감염능이 탁월한 새로운 PERV가 발생 할 가능성이 높은 것으로 사료된다. 본 연구진 에 의해 연구된 PERV의 자연 재조합율은 최소 $3 \%$ 이상인 것으로 조사 되었다(data not shown). 비록 PERV-A와 PERV-B간의 재조합이 며, 기능성을 가지지 못한 재조합체였지만, 재 조합이 매우 빈번히 일어나고 있음을 유추할 수 있다.

\section{RFLP에 의한 PERV의 분류}

PERV env 유전자 염기서열에서 PERV의 각 종류 별 특이적인 염기서열 부분이 있는데, 이 부분은 모두 숙주 세포의 수용체와 결합하는 receptor binding domain에 위치함을 알 수 있었 다. 조사된 각 $\mathrm{PERV}$ 의 특이적인 염기서열들을 이용하여 RFLP에 의한 PERV 분류법을 구축하 였다. PERV-A와 PERV-B를 모두 증폭할 수 있 는 primer (PERV-F 및 PERV-R)를 이용하여 PCR 반응을 수행 한 후 제한효소 $\mathrm{BamHI}$ 에 의 한 RFLP 결과, PERV-A는 절단이 일어나서 81 $\mathrm{bp}$ 와 $420 \mathrm{bp}$ 로 나눠지게 되고, PERV-B는 절단 이 일어나지 않아 $557 \mathrm{bp}$ 를 유지하였다(Fig. 5). 본 연구에서 사용한 모든 공시 동물의 genomic DNA에서 이러한 방법으로 PERV-A와 PERV-B 가 존재함을 확인할 수 있었다.

이종 간 장기 이식이 실용화되기 위해서는 생리학적 문제, 면역학적 문제들과 더불어 인 수 공통 감염의 문제 또한 해결되어야할 과제 이다. PERV는 무균사육으로도 제거 할 수 없 는 내인성 바이러스로서 in vitro 상에서 인간세 포로의 감염이 밝혀졌으며, 그 сору수 또한 일 반적인 유전자 적중(gene targeting)을 통하여 제

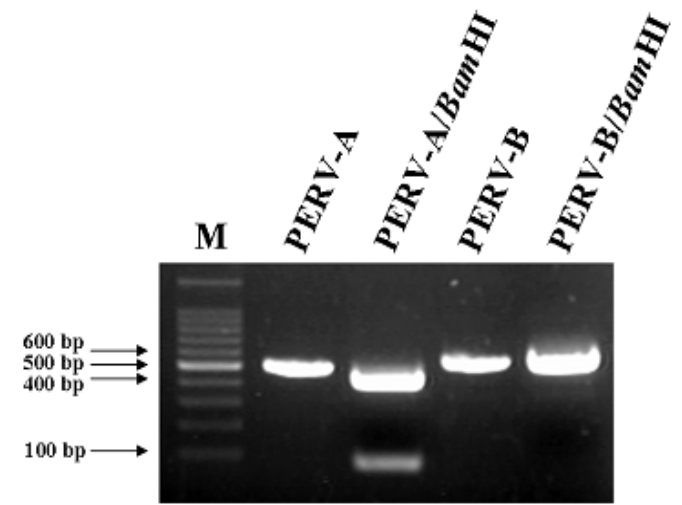

Fig. 5. Restriction fragment length polymorphism (RFLP) patterns of PERV-A and PERV-B. The DNA fragments were amplified with RFLP-specific primers (PERV-F \& PERV-R) and then digested with BamHI. These patterns of PERV-A and PERV-B were found in all pigs used in this study.

거할 수 있는 수준을 넘어선 32-64 copy를 가 지고 있는 것으로 보고되었다(Patience 등, 2001). Lee 등(2002)에 의하면 돼지 유전체 내 에 최소 32개(PERV-A 19개, PERV-B 13개)의 $\mathrm{PERV}$ 삽입 자리가 존재하는 것으로 알려져 있 다. 하지만 대부분의 PERV는 결손, 돌연변이 등에 의하여 제대로 바이러스를 형성하지 못하 고 있으며, Niebert와 Tonjes (2003)에 의하면 돼 지 유전체에서 복제 가능한 6개의 replication competent PERV를 발견 했다고 하였다. 현재 진행 되고 있는 PERV 제어 방법에는 siRNA에 의한 PERV의 제어(Karlas 등, 2004; Miyagawa 등, 2005), PERV가 적은 돼지 품종을 육종을 통하여 제거 하는 법 등 다양한 방법으로 접근 이 이루어지고 있다. 본 연구진이 개발한 PCR 을 이용한 PERV의 검출 및 각 종류(PERV-A, PERV-B 및 PERV-C) 별 검출 방법은 효율적으 로 PERV를 제어하는 시스템 개발 및 $\mathrm{PERV}$ 감 염의 검색 등에 있어서 기본적인 방법으로 활 용될 수 있으리라 사료된다. 


\section{IV. 요 약}

돼지의 내인성 레트로 바이러스인 PERV의 존재는 돼지의 무균 사육을 통해서도 제거할 수 없으며, 장기 이식 시 인수 공통 감염의 위 험성을 내포하고 있으므로, 이종 간 장기 이식 시 면역 거부 반응과 더불어 해결해야 할 가장 큰 문제점 중의 하나이다. 본 연구에서는 국내 에서 사육되고 있는 Berkshire, Duroc, Landrace, Yorkshire 종을 비롯하여 국내 미니 돼지 및 제 주도 토종 흑돼지에서 PERV의 존재 유무 및 종류에 대하여 확인 및 검출하는 중합효소 연 쇄반응(PCR) 기반 기법을 확립하였다. 사용된 모든 공시 돼지의 genomic DNA로부터 PERVA 및 PERV-B가 모두 검출되었으며, PERV-C의 경우 음성대조구인 PK15 세포에서의 결과와 비교했을 때, Duroc종에서 매우 낮은 양의 PCR 산물이, 국내 미니돼지와 제주 토종 흑돼지에 서는 상대적으로 높은 양의 PCR 산물이 검출 되었다. 또한 PERV-A와 PERV-B의 경우 특이 적 primer와 제한효소 $\mathrm{BamHI}$ 을 이용한 PCR$\mathrm{RFLP}$ 를 통하여 확인할 수 있었다. 본 연구의 $\mathrm{PERV}$ 검출법은 이종 간 장기 이식 시 PERV에 대한 안전 검정 및 $\mathrm{PERV}$ 의 분류 방법으로서 활용가능할 것으로 사료된다.

\section{V. 사 사}

본 연구는 학술진흥재단 젊은 과학자 연구 (KRF-2005-F00008-100015) 지원으로 수행되었 습니다.

\section{VI. 인 용 문 헌}

1. 김영봉, 박홍양, 이동희, 이정은. 2006. 무균돼지 내인성 레트로 바이러스의 엔벨로프 단백질 및 유전자. 특허 제 10-0657012호.

2. 김영봉, 유재영, 이종영, 김계웅, 박홍양. 2004. 국내 돼지에 존재하는 내인성 레트로 바이러스 의 분포. 한국동물자원과학회지 46(3):307-314.

3. 이동희, 유재영, 이정은, 김계웅, 박홍양, 이훈택,
김영봉. 2005. 국내 돼지에 존재하는 내인성 레 트로 바이러스의 엔밸로프 유전자 클로닝 및 분 자 계통학적 분석. 한국동물자원과학회지 47(2): 177-186.

4. 이동희, 이정은, 권무식, 박홍양, 김영봉. 2004. 무균돼지에 존재하는 내인성 레트로 바이러스 PERV-A와 PERV-B Envelope 유전자 클로닝. 대 한미생물학회지 34(4):373-380.

5. 이정은, 이동희, 유재영, 김계웅, 박홍양, 이훈택, 김영봉. 2006. 국내 돼지에서 분리한 내인성 레 트로 바이러스 $g a g$ 유전자의 분자 생물학적 특 성 분석. 대한미생물학회지 36(3):185-194.

6. Breese, S. S. Jr. 1970. Virus-like particles occurring in cultures of stable pig kidney cell lines. Brief report. Arch. Gesamte. Virusforsch. 30(4):401-404.

7. Clemenceau, B., Jegou, D., Martignat, L. and Sai, P. 2002. Microchimerism and transmission of porcine endogenous retrovirus from a pig cell line or specific pathogen-free pig islets to mouse tissues and human cells during xenografts in nude mice. Diabetologia 45(6):914-923.

8. Deng, Y. M., Tuch, B. E. and Rawlinson, W. D. 2000. Transmission of porcine endogenous retroviruses in severe combined immunodeficient mice xenotransplanted with fetal porcine pancreatic cells. Transplantation 70(7):1010-1016.

9. Dinsmore, J. H., Manhart, C., Raineri, R., Jacoby, D. B. and Moore, A. 2000. No evidence for infection of human cells with porcine endogenous retrovirus (PERV) after exposure to porcine fetal neuronal cells. Transplantation 70(9):1382-1389.

10. Dorling, A. 2002. Clinical xenotransplantation: pigs might fly? Am. J. Transplant. 2(8):695-700.

11. Ericsson, T. A., Takeuchi, Y., Templin, C., Quinn, G., Farhadian, S. F., Wood, J. C., Oldmixon, B. A., Suling, K. M., Ishii, J. K., Kitagawa, Y., Miyazawa, T., Salomon, D. R., Weiss, R. A. and Patience, C. 2003. Identification of receptors for pig endogenous retrovirus. Proc. Natl. Acad. Sci. USA 100(11):6759-6764.

12. Harrison, I., Takeuchi, Y., Bartosch, B. and Stoye, 
J. P. 2004. Determinants of high titer in recombinant porcine endogenous retroviruses. J. Virol. 78(24):13871-13879.

13. Klymiuk, N., Muller, M., Brem, G. and Aigner, B. 2002. Characterization of porcine endogenous retrovirus gamma pro-pol nucleotide sequences. J. Virol. 76(22):11738-11743.

14. Klymiuk, N., Muller, M., Brem, G. and Aigner, B. 2003. Recombination analysis of human-tropic porcine endogenous retroviruses. J. Gen. Virol. 84 (Pt 10):2729-2734.

15. Lee, D., Lee, J., Uhm, S. J., Lee, Y. S., Park, M. J., Park, H. Y., Kwon, M., Lee, H. T. and Kim, Y. B. 2006. Molecular characterization of the porcine endogenous retrovirus subclass $\mathrm{A}$ and $\mathrm{B}$ envelope gene from pigs. Transplant. Proc. 38(9):3066-3069.

16. Lee, J. H., Webb, G. C., Allen, R. D. and Moran, C. 2002. Characterizing and mapping porcine endogenous retroviruses in Westran pigs. J. Virol. 76(11):5548-5556.

17. Levy, M. F., Crippin, J., Sutton, S., Netto, G., McCormack, J., Curiel, T., Goldstein, R. M., Newman, J. T., Gonwa, T. A., Banchereau, J., Diamond, L. E., Byrne, G., Logan, J. and Klintmalm, G. B. 2000. Liver allotransplantation after extracorporeal hepatic support with transgenic (hCD55/hCD59) porcine livers: clinical results and lack of pig-to-human transmission of the porcine endogenous retrovirus. Transplantation 69(2):272280.

18. Magre, S., Takeuchi, Y. and Bartosch, B. 2003. Xenotransplantation and pig endogenous retroviruses. Rev. Med. Virol. 13(5):311-329.

19. Mang, R., Maas, J., Chen, X., Goudsmit, J. and van Der Kuyl, A. C. 2001. Identification of a novel type $\mathrm{C}$ porcine endogenous retrovirus: evidence that copy number of endogenous retroviruses increases during host inbreeding. J. Gen. Virol. 82(Pt 8):1829-1834.

20. Mollnes, T. E. and Fiane, A. E. 1999. Xenotransplantation: how to overcome the complement obstacle ? Mol. Immunol. 36(4-5):269-276.

21. Niebert, M. and Tonjes, R. R. 2003. Analyses of prevalence and polymorphisms of six replicationcompetent and chromosomally assigned porcine endogenous retroviruses in individual pigs and pig subspecies. Virology 313(2):427-434.

22. Niebert, M. and Tonjes, R. R. 2005. Evolutionary spread and recombination of porcine endogenous retroviruses in the suiformes. J. Virol. 79(1):649654.

23. Paradis, K., Langford, G., Long, Z., Heneine, W., Sandstrom, P., Switzer, W. M., Chapman, L. E., Lockey, C., Onions, D. and Otto, E. 1999. Search for cross-species transmission of porcine endogenous retrovirus in patients treated with living pig tissue. The XEN 111 Study Group. Science 285(5431):1236-1241.

24. Patience, C., Patton, G. S., Takeuchi, Y., Weiss, R. A., McClure, M. O., Rydberg, L. and Breimer, M. E. 1998. No evidence of pig DNA or retroviral infection in patients with short-term extracorporeal connection to pig kidneys. Lancet 352(9129):699-701.

25. Patience, C., Switzer, W. M., Takeuchi, Y., Griffiths, D. J., Goward, M. E., Heneine, W., Stoye, J. P. and Weiss, R. A. 2001. Multiple groups of novel retroviral genomes in pigs and related species. J. Virol. 75(6):2771-2775.

26. Patience, C., Takeuchi, Y. and Weiss R. A. 1997. Infection of human cells by an endogenous retrovirus of pigs. Nat. Med. 3(3):282-286.

27. Pitkin, Z. and Mullon, C. 1999. Evidence of absence of porcine endogenous retrovirus (PERV) infection in patients treated with a bioartificial liver support system. Artif. Organs 23(9):829-833.

28. Specke, V., Plesker, R., Coulibaly, C., Boller, K., and Denner, J. 2002a. Productive infection of a mink cell line with porcine endogenous retroviruses (PERVs) but lack of transmission to minks in vivo. Arch. Virol. 147(2):305-319.

29. Specke, V., Schuurman, H. J., Plesker, R., Coulibaly, C., Ozel, M,. Langford, G., Kurth, R., 
and Denner, J. 2002b. Virus safety in xenotransplantation: first exploratory in vivo studies in small laboratory animals and non-human primates. Transpl. Immunol. 9(2-4):281-288.

30. Swindle, M. M. 1996. Considerations of specific pathogen-free swine (SPF) in xenotransplantation. J. Invest. Surg. 9(4):267-271.

31. Swindle, M. M. 1998. Defining appropriate health status and management programs for specificpathogen-free swine for xenotransplantation. Ann. N. Y. Acad. Sci. 862:111-120.

32. Tacke, S. J., Kurth, R. and Denner, J. 2000. Porcine endogenous retroviruses inhibit human immune cell function: risk for xenotransplantation? Virology 268(1):87-93.

33. Takeuchi Y, Patience C., Magre S., Weiss RA, Banerjee PT, Le Tissier P. and Stoye JP. 1998. Host range and interference studies of three classes of pig endogenous retrovirus. $\mathrm{J}$ Virol
72(12):9986 9991.

34. van der Laan, L. J., Lockey, C., Griffeth, B. C., Frasier, F. S., Wilson, C. A., Onions, D. E., Hering, B. J., Long, Z., Otto, E., Torbett, B. E. and Salomon, D. R. 2000. Infection by porcine endogenous retrovirus after islet xenotransplantation in SCID mice. Nature 407(6800):90-94.

35. Weiss, R. A., Magre, S. and Takeuchi, Y. 2000. Infection hazards of xenotransplantation. J. Infect. 40(1):21-25.

36. White, S. A. and Nicholson, M. L. 1999. Xenotransplantation. Br. J. Surg. 86(12):1499-1514.

37. Wilson, C. A, Wong, S., Muller, J., Davidson, C. E., Rose, T. M. and Burd, P. 1998. Type C retrovirus released from porcine primary peripheral blood mononuclear cells infects human cells. J. Virol. 72(4):3082-3087.

(접수일자 : 2007. 3. 21. / 채택일자 : 2007. 6. 5.) 